Available online at GSC Online Press Directory

GSC Advanced Research and Reviews e-ISSN: 2582-4597, CODEN (USA): GARRC2

Journal homepage: https://www.gsconlinepress.com/journals/gscarr

(RESEARCH ARTICLE)

\title{
Antiplasmodial, antioxidant and toxicological study of leaves extracts of Dalbergia katangensis Lecheneaud (Fabaceae) from Eastern DR Congo
}

\author{
Bashige Chiribagula Valentin 1, 2, 3, ${ }^{*}$, Bakari Amuri Salvius ${ }^{1}$, Kahumba Byanga Joseph 1, Okusa Ndjolo \\ Philippe $^{2}$ and Lumbu Simbi Jean-Baptiste ${ }^{3}$ \\ ${ }^{1}$ Laboratoire de pharmacognosie - Faculté des Sciences Pharmaceutiques - Université de Lubumbashi- 27, av Kato, \\ Commune Kampemba, Lubumbashi-DR Congo. \\ 2 Service de chimie thérapeutique et analyse des substances naturelles-Faculté des Sciences Pharmaceutiques (UNILU) - \\ 27, av Kato, Commune Kampemba, Lubumbashi-DR Congo. \\ ${ }^{3}$ Laboratoire de Chimie organique - Faculté des Sciences Université de Lubumbashi- 2 av de la maternité, Commune de \\ Lubumbashi -Lubumbashi-DR Congo.
}

Publication history: Received on 13 August 2020; revised on 22 August 2020; accepted on 26 August 2020

Article DOI: https://doi.org/10.30574/gscarr.2020.4.2.0066

\begin{abstract}
Dalbergia katangensis is used in traditional medicine in Bukavu in management of malaria. In this study, antiplasmodial, antioxidant activities, and toxicological studies where carried out on aqueous and methanolic extracts of its leaves. The plant was selected following an ethnobotanical survey conducted in DR Congo and focusing on plants used traditionally to treat malaria. Extrac's phytochemical secondary metabolites were determined using standard procedures and the antiplasmodial activity was evaluated using 4-day suppressive test, while antioxidant activity was evaluated by DPPH assay. In acute toxicity, twenty animals (5/group) were given orally singular $2000 \mathrm{mg}$ of extract/kg body weight (BW) then observed for 14 days. In sub-acute toxicity assay, 200, $400 \mathrm{mg} / \mathrm{kg} \mathrm{BW/Day}$ were given orally, and animals were observed for 28 days. The total phenolic (0.58-0.61 $\mathrm{mg} \mathrm{GAEg}^{-1}$ ), total flavonoid (0.14-0.15 $\mathrm{mg} \mathrm{QEg}^{-1}$ ) and total terpenoids contents $(0.32-0.55 \% \mathrm{w} / \mathrm{w})$ were in the same rate in the two extracts as well as the antioxidant activity with IC 50 value $1.55 \pm 0.012$ and $1.71 \pm 0.014 \mu \mathrm{g} / \mathrm{mL}$. At the highest oral dose,400 mg/kg body weight, all extracts produced $73-75 \%$ chemo-suppression against $P$. berghei ANKA and 28 survival days. No deaths were recorded during the acute toxicity assay suggesting the $\mathrm{LD}_{50}>2000 \mathrm{mg} / \mathrm{kg}$ and no abnormal behavior or variation in toxicity biomarkers were observed during the subacute toxicity assessment. Dalbergia katangensis leaves extracts showed a great antiplasmodial and a very good antioxidant activity. It can be used to prepare antimalarial recipe or isolate antimalarial compounds in the future.
\end{abstract}

Keywords: Bukavu; antimalarial; DPPH; Plasmodium berghei; Mus norvegicus; Mus musculus

\footnotetext{
* Corresponding author: Bashige Chiribagula Valentin

Laboratoire de pharmacognosie - Faculté des Sciences Pharmaceutiques - Université de Lubumbashi- 27, av Kato, Commune Kampemba, Lubumbashi-DR Congo.
} 


\section{Graphical Abstract}

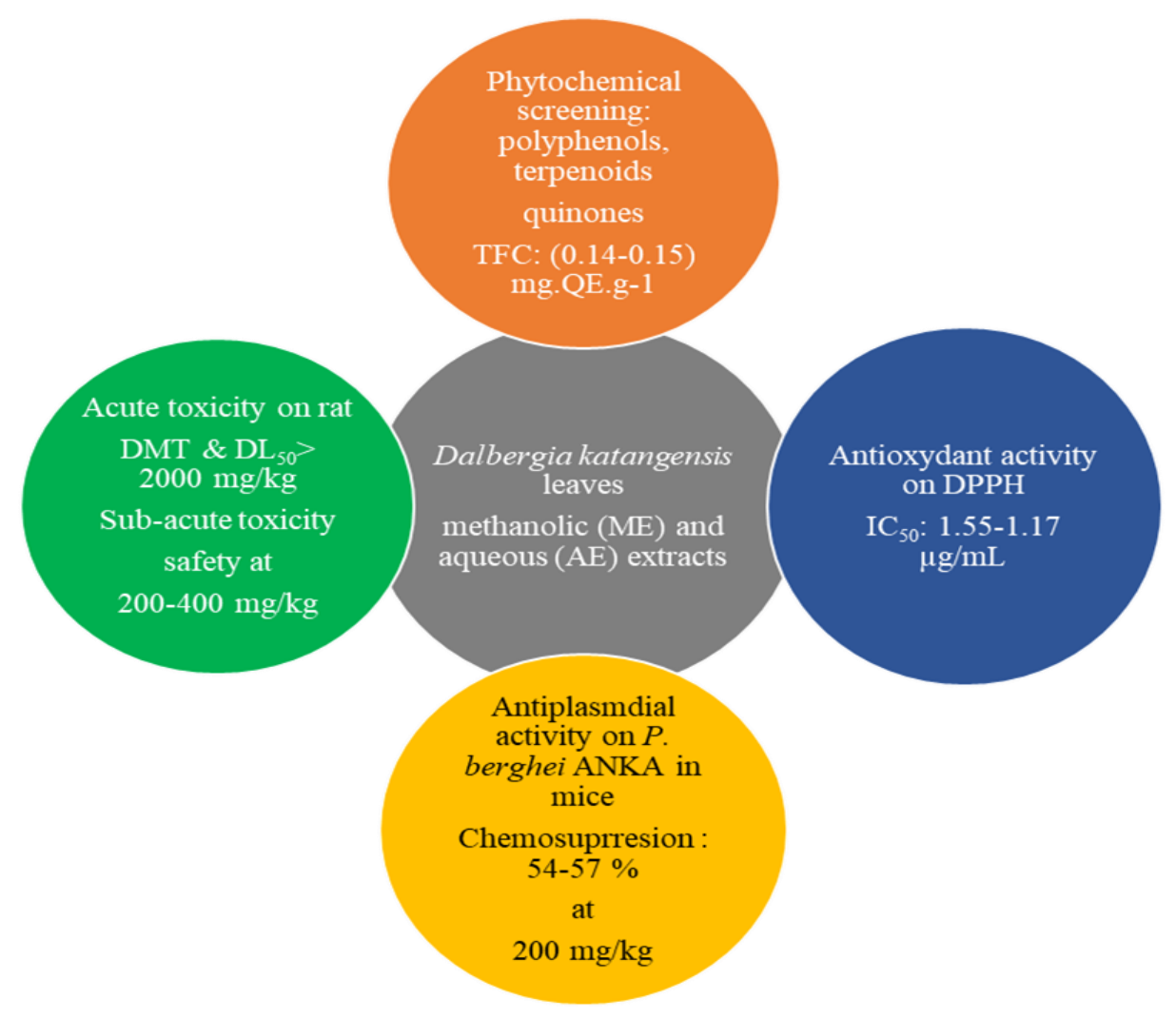

\section{Introduction}

Malaria is one of the most prevalent and serious protozoan tropical diseases which causes millions of clinical cases worldwide each year, and approximatively 1 million of death annually [1]. The World Health Organization (WHO) African Region accounted for $93 \%$ of all cases in 2018 and more than half of all cases were in six countries: Nigeria (25\% of cases), Democratic Republic of Congo, DRC (12\%), Uganda (5\%), Ivory Coast, Mozambica and Niger, 4\% each [2]. DRC is one of the central African country where malaria with Plasmodium falciparum is highly endemic with $97 \%$ of prevalence [3], being one of the most important health problems in the country [4].

Many Congolese people do not have access to modern health care and use medical plants, but many plants used in traditional medicine have not been studied [5]. Another element of the antimalarial control strategy would consist in validating the use of antimalarial plants with the hope to discover new compounds or produce improved traditional drugs. Studies have been conducted to search for antimalarial plants both across the world, in America [6,7], in Asia $[8,9]$ as well as in Africa [10,11] and particularly in DRC [12,13].

In Bukavu, among the many plants reported as antimalarials [5,14] we have selected Dalbergia katangensis Lecheneaud (Fabaceae) [4]. It is a tree from which there is not much information in the literature. The plant is locally named Mungobole, Nfuma (shi), Munyereza (fulero), and it's used in the treatment of malaria and other infectious diseases such vaginitis, bacillary dysentery (root bark), cholera, tuberculosis (stem bark) and conjunctivitis (leaves). This plant has already been investigated for in vitro antiplasmodial activity, study which revealed a great activity [4]. However, no information is reported on its phytochemical composition nor on the in vivo antimalarial activity, and toxicity.

This study aims to evaluate the antiplasmodial activity in vivo and antioxidant in vitro of methanolic, and aqueous extracts of the leaves of Dialium angolense. On this same occasion, we evaluate the acute and subacute toxicity on rats, and we look for large phytochemical groups mainly secondary metabolites with antimalarial potentiality. 


\section{Material and methods}

\subsection{Plant material and experimental animals}

Leaves of Dalbergia katangensis were collected from Bagira ( $2^{\circ} 28^{\prime} 12.9^{\prime \prime}$; $\left.28^{\circ} 49^{\prime} 18^{\prime \prime} \mathrm{E} ; 2,883.1 \mathrm{~m}\right)$ in june 2015 , and was identified at the herbarium of Meise in Belgium with the following voucher number: BR0000018879285. Healthy Mus musculus $(21.6 \pm 2.1 \mathrm{~g})$ and Mus norvegicus $(265.4 \pm 0.73 \mathrm{~g})$ male were procured from animals holding unit of Institut National de Recherches Biomédicales (INRB) Kinshasa-DRC. The animals were acclimatized to $28^{\circ} \mathrm{C}$ one week before the experiment by being subjected to a $12 \mathrm{~h}$ light-dark cycle, consuming a standard rodent food (MIDEMA/DRC) and drinking ad libitum.

\subsection{Chemicals and reagents}

Quinine $\mathrm{HCl}$, Ascorbic acid, 1,1-diphenyl-2- picrylhydrazyl radical (DPPH), Gallic acid, Quercetin, have been provided from (Sigma-Aldrich (USA) and all chemicals were of analytical grade.

\subsection{Preparation of extracts}

Methanolic extracts (ME) were obtained by macerating $350 \mathrm{~g}$ of dried leaves powder in $1.5 \mathrm{~L}$ of methanol (SigmaAldrich, USA). After $72 \mathrm{~h}$, the extract was filtered on paper (Whatman, USA) and the residue was macerated twice in a similar manner. The filtrates were combined, concentrated, and dried using a rotavapor (Büchi R-210, Switzerland) at $40^{\circ} \mathrm{C}$ under reduced pressure;130-180 mbar (yield, $12.1 \%, \mathrm{~W} / \mathrm{W}$ ). Aqueous extracts (AE) were prepared according to the protocol used in traditional medicine by decocting $340 \mathrm{~g}$ of the sample in $1.5 \mathrm{~L}$ for 25 minutes of local tap water (boiling for $0.5 \mathrm{~h}$ in a close recipient and filtration on paper). The extract was lyophilized (yield, 10.5\%, W/W) and for alltest, the extract was dissolve in $\mathrm{NaCl} 0.9 \%$.

\subsection{Phytochemical screening}

The plant extract was analyzed for the presence of some secondary metabolite including alkaloids, coumarins, flavonoids, saponins, steroids, tannins, terpenoids and phenols, using standard procedures in tube reaction [15,16].

\subsection{Total phenolic, flavonoids and terpenoids contents}

The total phenolics content of each sample was measured by a Folin-Ciocalteu method [17] and expressed as milligrams gallic acid equivalents per gram of dry plant extract (mg GAE/g DE) through a calibration curve gallic acid ( $\mathrm{y}=0.014 \mathrm{x}$ $+0.003, \mathrm{R}^{2}=0.997$; linearity range, $0.5-200 \mathrm{mg} . \mathrm{mL}^{-1}$ ). The total flavonoids content was determined using an aluminum trichloride assay [18] and expressed as milligrams quercetin equivalents per gram of dry plant extract (mg QE/g DE) through the calibration curve of quercetin $\left(y=0.006 \mathrm{x}+0.004, \mathrm{R}^{2}=0.998\right.$; linearity range, 0.1 to $\left.150 \mathrm{mg} / \mathrm{mL}\right)$. Regarding the determination of total terpenoids contents, dried plant extract $100 \mathrm{mg}$ (A) was taken and soaked in $9 \mathrm{~mL}$ of ethanol (Sigma-Aldrich, USA) for 24 hours. The extract after filtration was taken up by $10 \mathrm{~mL}$ of petroleum ether (Sigma-Aldrich, USA) using separating funnel. The ether extract was separated in pre-weighed glass vials and waited for its complete drying (B). Ether was evaporated and the yield (\%) of total terpenoids contents (TTC) was measured by the formula:

$\% \mathrm{TTC}=\mathrm{A}-\mathrm{B}[19]$. (Equation 1).

\subsection{Antioxidant activity-DPPH Assay}

DPPH radical scavenging activity of the plant extracts at varying concentrations $(1.95-125 \mu \mathrm{g} / \mathrm{mL})$ were measured in vitro via the DPPH assay [20]. Briefly, $50 \mu \mathrm{L}$ of extract prepared at different concentrations were interacted with 1950 $\mu \mathrm{L}$ of $0.002 \%$ DPPH in a plate 96 wells (Nunc WVR, Germany) giving concentrations of extracts ranging from 0.048 to $3.125 \mu \mathrm{g} / \mathrm{mL}$. After mixing and incubating in the dark for 30 minutes, the solution was read at $492 \mathrm{~nm}$ (Thermo Fisher Scientific Inc., Waltham, USA). The tests were carried out in triplicate. The percentage of antioxidant activity (AOA) was calculated by the formula:

$$
\% \mathrm{AAO}=\frac{(\mathrm{Ab}-\mathrm{Ae}) \times 100}{\mathrm{Ab}}(\text { Equation } 2)
$$

$\mathrm{Ab}=$ absorbance measured in the presence of the negative control, $\mathrm{Ae}=$ absorbance measured in the presence of the extract, and \% AAO = Percentage of inhibition. Depending on their IC $_{50}$ values, extracts were classified as following: (i) very active if $\mathrm{IC}_{50} \leq 5 \mu \mathrm{g} / \mathrm{mL}$, (ii) active if $5 \mu \mathrm{g} / \mathrm{mL} \leq \mathrm{IC}_{50} \leq 15 \mu \mathrm{g} / \mathrm{mL}$, (iii) moderately active if $15 \mu \mathrm{g} / \mathrm{mL}<\mathrm{IC}_{50}<50$ $\mu \mathrm{g} / \mathrm{mL}$, (iv) weakly active if $\mathrm{IC}_{50} \geq 50 \mu \mathrm{g} / \mathrm{mL}[20]$. 


\subsection{Antiplasmodial activity-4-day suppressive test}

The in vivo antiplasmodial activity of the extracts were evaluated using the 4-day suppressive test against Plasmodium berghei (ANKA MRA 311 supplied by the INRB) infections in mice [21]. Briefly, donor Mus musculus previously infected with Plasmodium berghei and having parasitemia level of 20-30\% were used to infect the experimental mice intraperitoneally with $0.2 \mathrm{~mL}$ of their infected blood. The infected mice were randomly divided into six groups of 5 each by weight. Three hours after inoculation, each Mus musculus was orally treated with $200 \mu \mathrm{L}$ of oral dose of the sample (200, $400 \mathrm{mg} \mathrm{kg}{ }^{-1}$ weight) daily for 4 days. A positive control-group received $10 \mathrm{mg} / \mathrm{kg} \mathrm{BW}$ of quinine per day, while the negative-control group animals were administered $200 \mu \mathrm{L}$ of the vehicle ( $\mathrm{NaCl} 0.9 \%)$. On day 4 , thin blood smear was made and stained with $10 \%$ Giemsa and examined under the light microscope with 100 times magnification to determine parasitemia level. Percentage of parasitemia was counted based on infected erythrocytes calculated per 1000 erythrocytes:

$\% \mathrm{P}=\frac{\text { Number of Parasitized RBCx100 }}{\text { Total Number of RBC Count }}$ (Equation 3). (RBC: Red Blood Cells).

From day 4 to day 7, thin blood smears were made from the tail of each Mus musculus, Giemsa stained and examined microscopically for assessment of parasitemia. On day 7, the level of parasitemia in each group of mice was determined so that the percentage chemo-suppression (TSP) were calculated as:

$\% \operatorname{TSP}=\frac{(\mathrm{A}-\mathrm{B}) \times 100}{\mathrm{~A}}($ Equation 4$)$

where A is the parasitemia in the negative-control group and B the parasitemia in the test group. All the mice were kept alive until the 28th day to assess the survival time (TS) [22,23]. In vivo antiplasmodial activity of extracts were classified as moderate, good, and very good if an extract displayed respective percent parasite suppression equal to or greater than $50 \%$ at doses of 500,250 , and $100 \mathrm{mg} / \mathrm{kg}$ body weight per day, respectively [24].

\subsection{Toxicological study}

Acute toxicity was carried out as described previously [25] using $2000 \mathrm{mg} / \mathrm{kg}$ by Weight (BW) in single dose (oral administration; 5 animals per group, followed over 14 days). In subacute toxicity, Mus norvegicus (5 each group) received orally for 28 days, 0 (negative control), 200 or $400 \mathrm{mg} / \mathrm{kg}$ BW/day. During blood collection and serum preparation for biochemical analysis, validated procedures were followed [25]. The activities of alkaline phosphatase (ALP), aspartate transaminase (AST), alanine transaminase (ALT), and the levels of urea and creatinine were determined by colorimetric assays with Labtest $($ kits (Minas Gerais, Brazil).

\subsection{Statistical analysis}

Values were analyzed using GraphPad Prism 6 (GraphPad Software, La Jolla, USA). Comparisons between different groups were carried out by analysis of variance, ANOVA; a probability level $\mathrm{p}<0.05$ was considered significant.

\subsection{Ethical approval}

The principles governing the use of laboratory animals as laid out by Organization for Economic Co-operation and Development: OECD, Minna Committee on Ethics for Medical and Scientific Research and also existing internationally accepted principles for laboratory animal use and care as contained in the Canadian Council on Animal Care Guidelines and Protocol Review [26] were duly observed. The project proposal and procedures were reviewed and approved by the Department of Pharmacology in the faculty of Pharmaceutical Sciences from the University of Lubumbashi, DRC (UNILU/FSP/DPCOL/PT/002/2014).

\section{Results}

\subsection{Phytochemical screening of Dalbergia katangensis extracts}

The phytochemical screening of D. katangensis leaves extracts revealed the presence of quinones, flavonoids, polyphenols, steroids, terpenoids, but the absence of alkaloids, coumarins, and saponins (Table 1). 
Table 1 Phytochemical composition of extract of Dalbergia katangensis.

\begin{tabular}{|l|c|c|}
\hline Phytochemical class & Aqueous extract (AE) & Methanolic extract (ME) \\
\hline Alkaloids & - & - \\
\hline Anthraquinones & + & + \\
\hline Coumarins & - & + \\
\hline Flavonoids & + & + \\
\hline Polyphenols & + & - \\
\hline Saponins & - & + \\
\hline Steroids & + & + \\
\hline Terpenoids & + & + \\
\hline
\end{tabular}

The different total phenolics content: TPC values vary between $0.58-0.61 \mathrm{mg} \mathrm{GAEg}^{-1}$ and are four times higher than the Total flavonoids content: TFC values $\left(0.14-0.15 \mathrm{mg} \mathrm{QEg}^{-1}\right)$. Total terpenoids content: TTC, vary between $0.3-0.5$ (\% W / W) and, a difference between aqueous and methanolic extracts is only observed with TTC with p $<0.01$ (Table 2).

Table 2 Total polyphenol, flavonoid and terpenoids contents of extract of $D$. katangensis

\begin{tabular}{|l|c|c|c|}
\hline Simple & Total phenolics content (TPC) & Total flavonoids content (TFC) & Total terpenoids content (TTC) \\
\hline & (mg GAEg-1) & $(\mathrm{mg}$ QEg-1) & $(\% \mathrm{w} / \mathrm{w})$ \\
\hline $\mathrm{ME}$ & $0.6120 \pm 0.011$ & $0.1530 \pm 0.014$ & $0.551 \pm 0.011$ \\
\hline $\mathrm{AE}$ & $0.5814 \pm 0.012$ & $0.1453 \pm 0.015$ & $0.323 \pm 0.03^{\mathrm{a}}$ \\
\hline
\end{tabular}

ME: Methanolic extract, AE: aqueous extract; Data are expressed as mean \pm SD $(n=3)$ and compared to ME; a if $\mathrm{p}<0.01$.

\subsection{Antioxidant activity}

The scavenging ability of the samples tested showed a dependent concentration activity profile. The anti-free radical activity expressed in the form of IC50-1 is respectively $1.55 \pm 0.012$ (AE) and $1.71 \pm 0.014 \mu \mathrm{g} / \mathrm{mL}$ suggesting a very good antioxidant activity of studied extracts according to the previously proposed classification [20]. No statistically significant difference was observed between the two extracts. In contrast, their antioxidant activity is lower ( $p<0.001$ ) than ascorbic acid used as a positive control (figure 1).

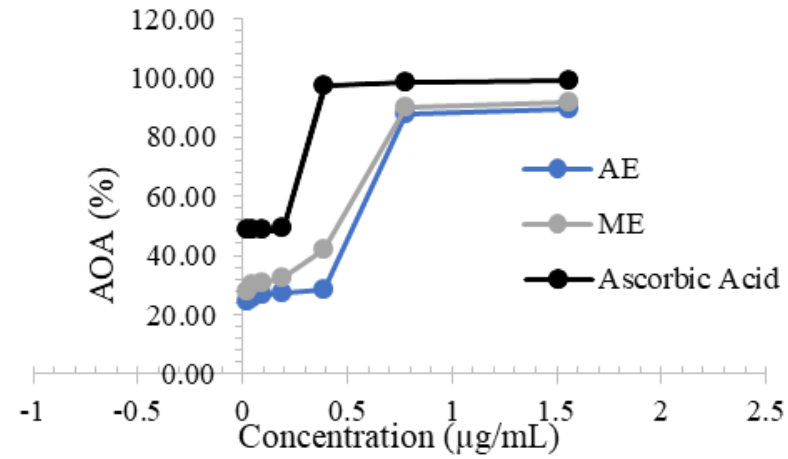

$1 \mathrm{a}$

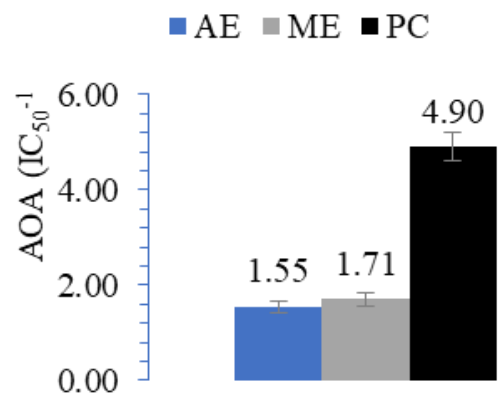

$1 \mathrm{~b}$

Figure 1 DPPH radical scavenging activities of Dalbergia katangensis expressed as a percentage (1a) and as the value of $\mathrm{IC}_{50^{-1}}$ in $\mu \mathrm{g} / \mathrm{mL}(1 \mathrm{~b})$. Positive control (PC): ascorbic acid. Data expressed as Mean $\pm \mathrm{SD}, \mathrm{n}=5$. AOA: antioxidant activity. AE: aqueous extract, ME: methanolic extract. 


\subsection{Antiplasmodial activity}

The percentage suppression analysis of the extracts showed decrease $(\mathrm{p}<0.01)$ in parasitemia at all dose levels as compared to the negative control group. The group received $400 \mathrm{mg} / \mathrm{kg} \mathrm{WB} /$ day (ME 400) exhibited maximal suppression $(74.81 \pm 0.05 \%)$; the effect was significantly lower than the group which received quinine $(\mathrm{p}<0.001)$. All doses of the extract significantly enhanced the survival time (TS) of the mice in a "not dose dependent manner" as compared to the negative control group (Table 3).

Table 3 Antiplasmodial activity of the different doses of the extracts of D. katangensis during established infection (Mean $\pm \mathrm{SD}, \mathrm{n}=5$ ).

\begin{tabular}{|l|l|l|l|l|}
\hline Group & $\begin{array}{l}\text { Dose } \\
\text { (mg/kg WB) }\end{array}$ & P (\%): Parasitemia & $\begin{array}{l}\text { Suppression Rate: } \\
\text { PSR (\%) }\end{array}$ & $\begin{array}{l}\text { TS(D): } \\
\text { Survival Time }\end{array}$ \\
\hline ME 200 & 200 & $4.86 \pm 0.05^{\mathrm{a}}$ & $57.02 \pm 0.25$ & 28 \\
\hline AE 200 & 200 & $5.12 \pm 0.02^{\mathrm{a}}$ & $54.73 \pm 0.03$ & 28 \\
\hline ME 400 & 400 & $2.85 \pm 0.18^{\mathrm{b}}$ & $74.81 \pm 0.05$ & 28 \\
\hline AE 400 & 400 & $3.01 \pm 0.23^{\mathrm{b}}$ & $73.38 \pm 0.15$ & 28 \\
\hline Quinine & 10 & $1.01 \pm 0.03^{\mathrm{c}}$ & $91.06 \pm 0.11$ & 28 \\
\hline NaCl 0,9\% & - & $11.31 \pm 0.02$ & NA & 10 \\
\hline
\end{tabular}

D: day. ME 200: Group treated with $200 \mathrm{mg} / \mathrm{kg}$ body weight methanolic extracts from leaves of Dalbergia katangensis. The results (P and PSR) express the values obtained on the 7th day. TS is obtained on the 28th day of observation, NA: Not applicable. All extracts are compared to negative control ( $\mathrm{NaCl} 0.9 \%)$; the level of significance of difference is expressed by letters $\mathrm{a}, \mathrm{b}, \mathrm{c}$; $\mathrm{a}$ if $\mathrm{p}<0.01, \mathrm{~b}$ if $\mathrm{p}<0.001,{ }^{\mathrm{c}}$ if $\mathrm{p}<0.0001$.

\subsection{Acute and sub-acute toxicities}

\subsubsection{Clinical signs, weight variation, maximum tolerated dose (DMT) and 50\% lethal dose of animal (LD50)}

When assessing acute toxicity, signs of asthenia, hair straightening and anorexia were observed in the test groups. On the other hand, during the evaluation of the subacute toxicity, no signs of toxicity were observed. No significant variation in weight was observed either during the assessment of acute toxicity or during the assessment of sub-acute toxicity (figure 2). Likewise, no variation in the weight of certain organs was observed during the evaluation of the subacute toxicity (figure 3). No death was recorded during the toxicological experimentation nor any serum variation of the biomarkers of the hepatic function (ASAT, ALAT, PAL) nor renal (urea, creatinine), in the treated groups (ME200, AE200, ME400, AE400) compared to the control group $(0.9 \% \mathrm{NaCl})$ (figure 3. c-d). Administration of therapeutic doses $(200$ and $400 \mathrm{mg} / \mathrm{kg}$ ) for 28 days of aqueous and methanolic extracts of the leaves of Dalbergia katangensis does not cause toxicity in Mus norvegicus. The DMT is thus estimated $>2000 \mathrm{mg} / \mathrm{kg}$ and the $\mathrm{LD}_{50}>2000 \mathrm{mg} / \mathrm{kg}$.

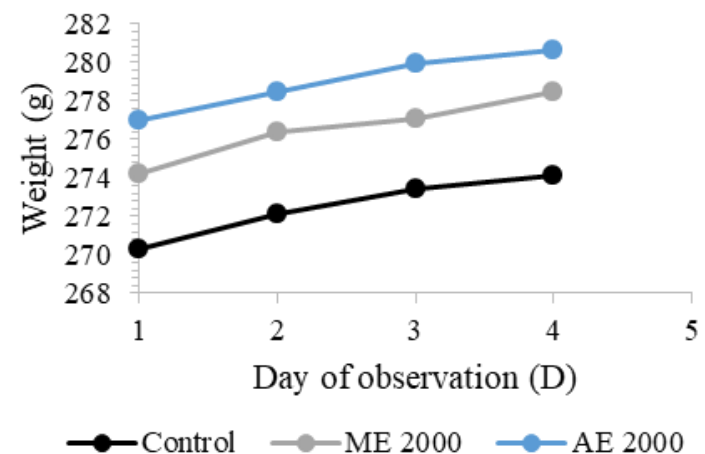

$2 \mathrm{a}$
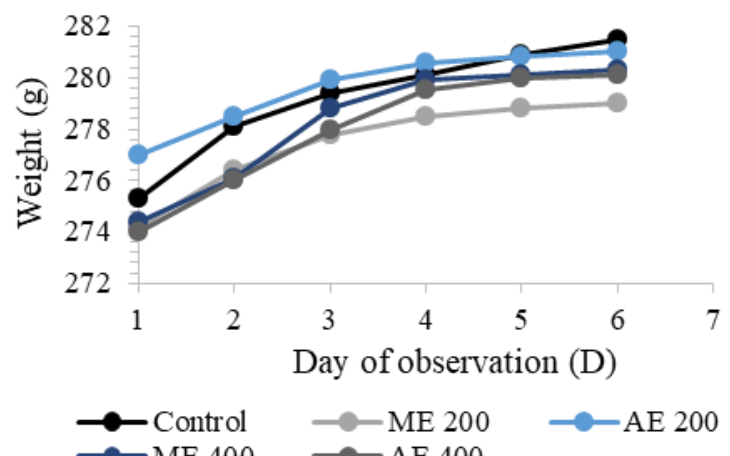

$-\operatorname{ME} 200$

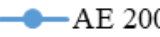

AE 200

$2 \mathrm{~b}$

Figure 2 Ponderal evolution of Mus norvegicus during the experimental (a): in acute toxicity, (b): in subacute toxicity). Data are expressed as mean $(n=5)$. Weights were taken every 7 days from the week, (D-7) preceding the day of the poisoning (D0). ME 2000: group received $2000 \mathrm{mg}$ of methanolic extract / $\mathrm{kg}$ BW in single dose. AE2000: group received $200 \mathrm{mg} / \mathrm{kg}$ BW of aqueous extracts. 


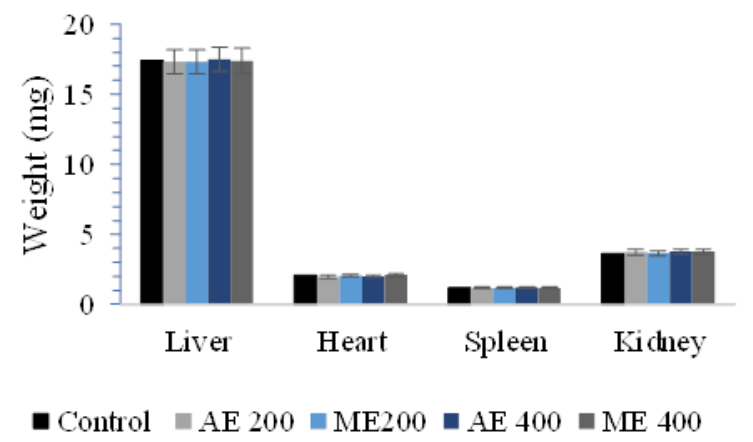

$3 a$

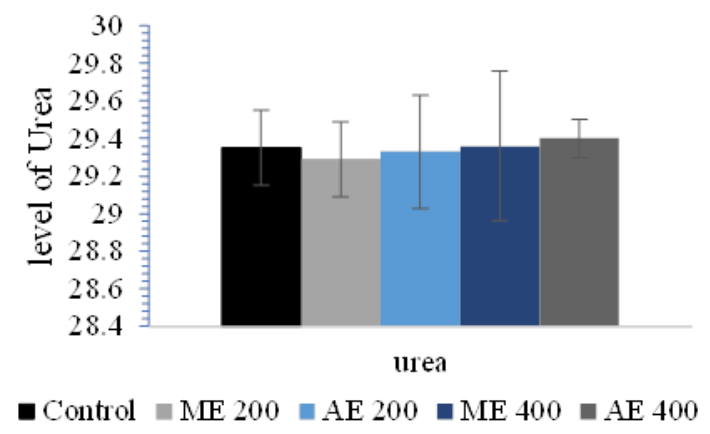

$3 c$

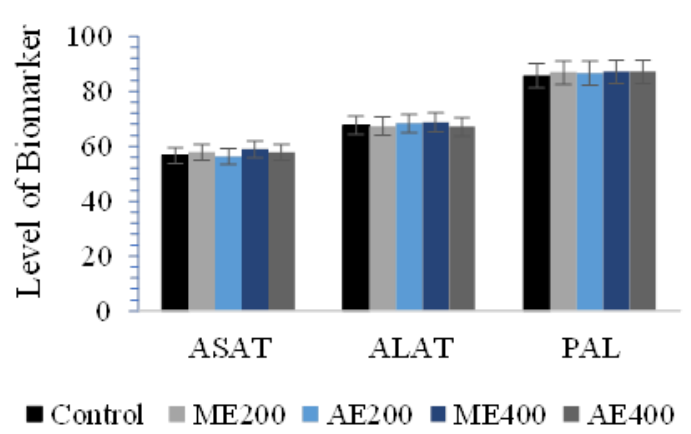

$3 b$

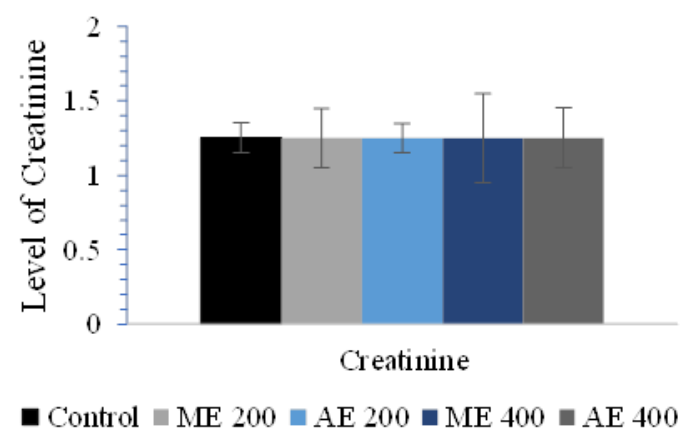

$3 d$

Figure 3 Mus norvegicus organs weight (a), hepatic (b) and renal (c, d) variation level of some biomarkers when exposed to Dalbergia katangensis extract, 200 and $400 \mathrm{mg} / \mathrm{kg}$ BW. ME200: Methanolic extract given at $200 \mathrm{mg} / \mathrm{kg}$ BW/day, AE400: Aqueous extract given at $400 \mathrm{mg} / \mathrm{kg}$ BW/day. Data expressed as Mean $\pm \mathrm{SD}, \mathrm{n}=5$.

\section{Discussion}

In this study, we provide knowledge on the aqueous and methanolic extracts of the leaves of Dalbergia katangensis regarding the phytochemical composition on secondary metabolites, the pharmacological activity (antiplasmodial in vivo on Plasmodium berghei and antioxidant in vitro on DPPH), the acute, and subacute toxicities in Mus norvegicus model. Water is the solvent used in traditional medicine during the preparation of antimalarial recipe based on $D$. katangensis leaves [4]. On the other hand, methanol, is the solvent most used during the biological screening of plants because it is easily handled, thanks to its great evaporative power. A concomitant test with the aqueous extract and the methanolic extract consists in varying the possibility of switching from the solvent used in traditional medicine to that used in the experimental laboratory.

This study reports a chemical similarity composition in secondary metabolites between methanolic and aqueous extract of leaves of $D$. katangensis by the concomitant presence of flavonoids, quinones, terpenoids and overall polyphenols (Table 1) suggesting the possible similarity in pharmacological activities. Several compounds with antioxidant [27-32] and antiplasmodial [33-37] activity from different groups identified within the leaves of Dalbergia katangensis during this study were isolated from many natural product, so that these groups are increasingly considered as groups with antimalarial and antioxidant potential.

No phytochemical study has been reported regarding D. katangensis; Nevertheless, other species of the same genus Dalbergia have been studied for phytochemical composition. During this study, we encountered in the two aqueous, and methanolic extracts, polyphenols, particularly flavonoids, quinones, steroids and terpenoids. Several phytochemical groups, including flavonoids, phenols, quinones, steroids, and terpenoids have been isolated from various species of the Dalbergia genus but mainly in the heartwood part. In Leaves theses phytochemical group have been found in $D$. sissoo DC, D. odorifera T.C.Chen, and D. lanceolaria L.f.; most compound isolated were polyphenols particularly flavonoids [38]. Isoflavones particularly apioglucoside has been proposed as a chemotaxonomic marker of the genus Dalbergia [39].

The methanolic extract from the leaves of D. katangensis (Table 2) contains the TPC tree times higher than that of $D$.

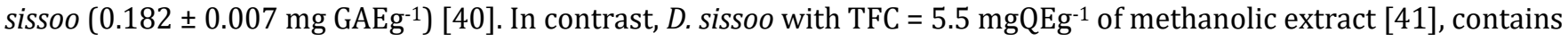


a TFC, 50 times greater than that of $D$. katangensis. The polyphenols, however abundant they may be in the leaves of $D$ katangensis, are mostly non-flavonoid.

This study (figure 1) confirms the interesting antioxidant activity of aqueous and methanolic extracts of Dalbergia katangensis leaves previously reported [20]. At the genus level, The antioxidant activity at DPPH, of the leaves of some species of the genus Dalbergia has been previously reported, in particular for D. paniculata Roxb, IC $50=70.6 \mu \mathrm{g} / \mathrm{mL}$ [42], D. odorifera T.C.Chen, IC50 $=5.1 \pm 0.12 \mu \mathrm{g} / \mathrm{mL}$ [43], D. brasiliensis Vogel, IC $50=74.5 \pm 1.3 \mu \mathrm{g} / \mathrm{mL}$ [44] and D. sissoo, IC $50=$ $3.2 \mu \mathrm{g} / \mathrm{mL}$ [45]. Obviously, D. katangensis (ME IC $50=0.58 \mu \mathrm{g} / \mathrm{mL}$ ) exhibits an antioxidant activity greater than that of the above-mentioned plant species. According to the classification proposed previously [20], this antioxidant activity of D. katangensis is very good and would very probably be linked to the presence of the polyphenolic compounds identified (Table 1) and quantified (Table 2) during this study, especially since phenolic compounds are known as antioxidants [46-48].

D. katangensis extracts sufficiently reduced parasitemia in the animals on day 7 of observation (Table 3) and these reductions in parasitemia were dose dependent. This situation is observed in plants with antimalarial activity in the rodent model and constitutes one pledge of their activities [49-51]. According to the classification previously proposed [52], all extract presented a good antiplasmodial activity in vivo. Some species of the genus Dalbergia have previously led to the isolation of antimalarial compounds. The antimalarial activity of the stem of D. parviflora Roxb. has been attributed to dalparvone, a flavonoid [53], that of D. louvelii R.Vig., was attributed to 4 compounds: (R)-4"methoxydalbergione(quinone),7,4'Dihydroxy-3-methoxyisoflavone(flavonoid), Obtusafuran (phenol) and isoliquiritigenin (Phenol) [54]. Isoliquiritigenin has also been reported in D. odorifera T.C.Chen [55] and D. cochinchinensis Laness [56]. It is therefore probable to discover within D. katangensis, antimalarial compounds resulting from these phytochemical groups identified in the plant during the present study (Table 1).

The leaves of $D$. katangensis exhibited an antiplasmodial activity positioned variously in relation to some antimalarial species from the DRC studied previously. Its activity is lower than the activity of the leaves of Senna occidentalis (L.) Link (Fabaceae): ME, TSP 73\% at $200 \mathrm{mg} / \mathrm{kg} \mathrm{BW} \mathrm{[57]} \mathrm{and} \mathrm{the} \mathrm{bark} \mathrm{of} \mathrm{the} \mathrm{roots} \mathrm{of} \mathrm{Alstonia} \mathrm{congensis} \mathrm{Engl.}$ (Apocynaceae): AE, TSP: $80.43 \pm 0.12 \mathrm{mg} / \mathrm{kg} \mathrm{BW} \mathrm{[1]} \mathrm{but} \mathrm{it} \mathrm{is} \mathrm{superior} \mathrm{to} \mathrm{the} \mathrm{leaves} \mathrm{of} \mathrm{Physalis} \mathrm{angulata} \mathrm{L} \mathrm{(Solanaceae):}$ $\mathrm{ME}, \mathrm{TSP}=60 \%$ at $300 \mathrm{mg} / \mathrm{kg}$ BW and Anisopappus chinensis Hook (Asteraceae): AE, TSP: $46.6 \%$ at $300 \mathrm{mg} / \mathrm{kg}$ [23].

At experimental doses of $200,400 \mathrm{mg} / \mathrm{kg}$ (subacute toxicity) and $2000 \mathrm{mg} / \mathrm{kg}$ (acute toxicity), the toxicity of $D$. katangensis has not been sufficiently established. We can assume, as for other previous studies on other species of the same genus, in particular D. sissoo DC. [58], D. saxatilis Hook.f. [59], D. monetaria L.f. [60], D. candenatensis (Dennst.) Prain [61], that the toxicity of D. katangensis leaves would only occur at higher doses. This information further supports the use of $D$. katangensis in traditional medicine. However, it should be noted that unlike these aforementioned species, D. katangensis showed some signs of toxicity during the acute toxicity assessment, suggesting that at doses higher than those used during this study, the plant would present some toxicity in vivo. This aspect should be considered in subsequent studies to establish the toxicological profile of this plant.

\section{Conclusion}

For the first time, a promising antiplasmodial activity in vivo against $P$. berghei on Mus musculus model with an interesting toxicological profile on Mus norvegicus is demonstrated for the leaves of Dalbergia katangensis and its antioxidant activity in vitro previously known is confirmed. This plant is particularly interesting for a further investigation as very few is known about its phytochemical composition.

\section{Compliance with ethical standards}

\section{Acknowledgments}

The authors sincerely thank ARES CCD for the funding which made it possible to carry out this study.

\section{Disclosure of conflict of interest}

The authors declare that they have not known competing financial interests or personal relationships that could have appeared to influence the work reported in this paper. 


\section{Statement of ethical approval}

The project proposal and procedures were reviewed and approved by the Department of Pharmacology in the faculty of Pharmaceutical Sciences from the University of Lubumbashi, DRC (UNILU/FSP/DPCOL/PT/002/2014).

\section{References}

[1] Cimanga RK, Nsaka SL, Tshodi ME, Mbamu BM, Kikweta CM, Makila FB-M, Pieters LC, Paul Maes LV, Arnold JE and Vassiliki TE. (2019). In vitro and in vivo antiplasmodial activity of extracts and isolated constituents of Alstonia congensis root bark. J Ethnopharmacol, 242, 111736.

[2] WHO. (2019). World Malaria Report 2019. WHO press, Geneve, 275.

[3] WHO. (2018). World malaria report 2018. WHO press, Geneva, 245.

[4] Bashige CV, Bakari AS, Ndjolo PO, Kahumba BJ, Duez P and Lumbu SJ. (2020). Ethnobotanical study of plants used as antimalarial in traditional medicine in Bagira in Eastern RD Congo. J Pharmacogn Phytochem, 9(4), 1-14.

[5] Mboni HM, Keymeulen F, Ngezahayo J, Amuri SB, Mutombo EK, Byanga JK, Duez P, Stévigny C and Lumbu S J-B. (2019). Antimalarial herbal remedies of Bukavu and Uvira areas in DR Congo: An ethnobotanical survey. J Ethnopharmacol, 249, 112422.

[6] Cai S, Risinger AL, Nair S, Peng J, Anderson TJC, Du L, Powell DR, Mooberry SL and Cichewicz RH. (2016). Identification of Compounds with Efficacy against Malaria Parasites from Common North American Plants. J Nat Prod, 79(3), 490-498.

[7] Do Nascimento MS, Pina N di PV, da Silva ASB, Gomes LF dos S, de Vasconcellos F, Brandão GC, Nascimento MFA, Oliveira AB and Barbosa WLR. (2019). In vitro antiplasmodial activity and identification, using tandem LC-MS, of alkaloids from Aspidosperma excelsum, a plant used to treat malaria in Amazonia. J Ethnopharmacol, 228, 99109.

[8] Bhat GP and Surolia N. (2016). In vitro antimalarial activity of extracts of three plants used in the traditional medicine of India. Am J Trop Med Hyg, 65(4), 304-308.

[9] Teklemichael AA, Mizukami S, Toume K, Mosaddeque F, Kamel MG, Kaneko O, Komatsu K, Karbwang J and Huy NT. (2020). Anti - malarial activity of traditional Kampo medicine Coptis rhizome extract and its major active compounds. Malar J, 19(204), 1-10.

[10] Gebrehiwot S, Shumbahri M, Eyado A and Yohannes T. (2019). Phytochemical Screening and in Vivo Antimalarial Activity of Two Traditionally Used Medicinal Plants of Afar Region, Ethiopia, against Plasmodium berghei in Swiss Albino Mice. J Parasitol Res, 1-8.

[11] Kweyamba PA, Zofou D, Efange N, Assob JCN and Kitau J. (2019). In vitro and in vivo studies on anti - malarial activity of Commiphora africana and Dichrostachys cinerea used by the Maasai in Arusha region, Tanzania. Malar J, 18(119), 1-6.

[12] Memvanga PB, Tona GL, Mesia GK, Lusakibanza MM and Cimanga RK. (2015). Antimalarial activity of medicinal plants from the democratic republic of Congo : A review. J Ethnopharmacol, 169(1), 76-98.

[13] Tshibangu PT, Kapepula PM, Kapinga MJK, Mukuta AT, Kalenda DT, Tchinda AT, Mouithys-Mickalad AA, Jansen O, Cieckiewicz E, Tits M, Angenot L and Frédérich M. (2017). Antiplasmodial activity of Heinsia crinita (Rubiaceae) and identification of new iridoids. J Ethnopharmacol, 196(1), 261-266.

[14] Kasali FM, Mahano AO, Nyakabwa DS, Kadima NJ, Misakabu FM, Tshibangu DST, Ngbolua KN and Mpiana PT. (2014). Ethnopharmacological Survey of Medicinal Plants Used against Malaria in Bukavu City (D. R. Congo). European J Med Plants, 4(1), 29-44.

[15] Bashige CV, Bakari AS, Numbi IE, Kalonda ME, Ndjolo OP, Kahumba B joh and Lumbu SJ. (2018). Criblage Phytochimique et activité antimicrobienne de sept fleurs comestibles utilisées en médecine traditionnelle à Lubumbashi ( RDC ). J Appl Biosci, 124, 12455-12467.

[16] Babakura M, Usman H, Gaidam YA, Halima UA and Fulata AM. (2019). Preliminary Phytochemical Screening , Analgesic and Anti-inflammatory Effects of the Hydroethanol and $\mathrm{n}$-Hexane Leaf Extracts of Maytenus senegalensis Lam . Excell . (Celestraceae ). South Asian Res J Nat Prod, 2(1), 1-9.

[17] Fu L, Xu BT, Gan RY, Zhang Y, Xu XR, Xia EQ and Li HB. (2011). Total phenolic contents and antioxidant capacities of herbal and tea infusions. Int J Mol Sci, 12(4), 2112-2124. 
[18] Koolen HHF, da Silva FMA, Gozzo FC, de Souza AQL and De Souza ADL. (2013). Antioxidant, antimicrobial activities and characterization of phenolic compounds from buriti (Mauritia flexuosa L. f.) by UPLC-ESI-MS/MS. Food Res Int, 51(2), 467-473.

[19] Malik SK, Ahmad M and Khan F. (2017). Qualtitative and quantitative estimation of terpenoid contents in some important plants of punjab , Pakistan. Pak J Sci, 69(2), 150-154.

[20] Bashige C valentin, Bakari AS, Okusa N, Kahumba BJ, Duez P and Lumbu SJ-B. (2020). Antiplasmodial , inhibitor of hemozoin synthesis and antioxidant activities of some plants used as antimalarial drugs in Bagira (DR Congo ). Int J Pharmacogn Clin Res, 2(1), 1-8.

[21] Habte G, Nedi T and Assefa S. (2020). Antimalarial Activity of Aqueous and 80 \% Methanol Crude Seed Extracts and Solvent Fractions of Schinus molle Linnaeus (Anacardiaceae ) in Plasmodium berghei -Infected Mice. J Trop Med, 1-9.

[22] Mesia GK, Tona GL, Penge O, Lusakibanza M and Nanga TM. (2005). Antimalarial activities and toxicities of three plants used as traditional remedies for malaria in the Democratic Republic of Congo : Croton mubango , Nauclea pobeguinii and Pyrenacantha staudtii. Ann Trop Med Parasitol, 99(4), 345-357.

[23] Lusakibanza M, Mesia G, Tona G, Karemere S, Lukuka A Tits M, Angenot L and Frédérich M. (2010). In vitro and in vivo antimalarial and cytotoxic activity of five plants used in congolese traditional medicine. J Ethnopharmacol, 129(3), 398-402.

[24] Chaniad P, Techarang T, Phuwajaroanpong A and Punsawad C. (2019). Antimalarial Activity and Toxicological Assessment of Betula alnoides Extract against Plasmodium berghei Infections in Mice. Evidence-Based Complement Altern Med, 1-8.

[25] Rasekh HR, Nazari P, Kamli-Nejad M and Hosseinzadeh L.(2018). Acute and subchronic oral toxicity of Galega officinalis in rats. J Ethnopharmacol, 116(1), 21-26.

[26] Canadian Council on Animal Care Guidelines and Protocol Review (CCAC). (1997). on AC. CCAC guidelines on : animal use protocol review, 3,11 .

[27] Perron NR and Brumaghim JL.(2009). A review of the antioxidant mechanisms of polyphenol compounds related to iron binding. Cell Biochem Biophys, 53(2), 75-100.

[28] Sunassee SN and Davies-Coleman MT. (2012). Cytotoxic and antioxidant marine prenylated quinones and hydroquinones. Nat Prod Rep, 29(5), 513-535.

[29] Rubió L, Motilva MJ and Romero MP. (2013). Recent Advances in Biologically Active Compounds in Herbs and Spices: A Review of the Most Effective Antioxidant and Anti-Inflammatory Active Principles. Crit Rev Food Sci Nutr, 53(9), 943-953.

[30] Moghrovyan A, Sahakyan N, Babayan A, Chichoyan N, Petrosyan M and Trchounian A. (2019). Essential Oil and Ethanol Extract of Oregano (Origanum vulgare L.) from Armenian Flora as a Natural Source of Terpenes, Flavonoids and other Phytochemicals with Antiradical, Antioxidant, Metal Chelating, Tyrosinase Inhibitory and Antibacterial Activity. Curr Pharm Des, 25(16), 1809-1816.

[31] Wang CY, Chen YW and Hou CY. (2019). Antioxidant and antibacterial activity of seven predominant terpenoids. Int J Food Prop, 22(1), 230-238.

[32] Miao Y, Wu Y, Jin Y, Lei M, Nan J and Wu X. (2020). Benzoquinone derivatives with antioxidant activity inhibit activated hepatic stellate cells and attenuate liver fibrosis in TAA-induced mice. Chem Biol Interact, $317,108945$.

[33] Onguéné A, Onguéné PA, Ntie-kang F, Lifongo LL, Ndom JC and Sippl W. (2014). The potential of anti-malarial compounds derived from African medicinal plants . Part I : A pharmacological evaluation of alkaloids and terpenoids. Malar J, 12(449), 1-26.

[34] Ntie-Kang F, Onguéné PA, Lifongo LL, Ndom JC, Sippl W and Mbaze LM. (2014). The potential of anti-malarial compounds derived from African medicinal plants , part II : a pharmacological evaluation of non-alkaloids and non-terpenoids. Malar J, 13(81), 1-20.

[35] Pan WH, Xu XY, Shi N, Tsang SW and Zhang HJ. (2018). Antimalarial activity of plant metabolites. Int J Mol Sci, 19(5), 1-40.

[36] Builders M. (2020). Antimalarial phenolic compounds in Africa : a review of biomedical and pharmaceutical sciences. Eur J Biomed Pharm Sci, 6(4), 6-11. 
[37] Tajuddeen N and Van Heerden FR. (2019). Antiplasmodial natural products: An update. Malar J, 18(1), 1-62.

[38] Saha S, Shilpi JA, Mondal H and Hossain F. (2013). Ethnomedicinal, phytochemical, and pharmacological profile of the genus Dalbergia L . ( Fabaceae ). Phytopharmacology, 4(2), 291-346.

[39] Innocent E. (2012). A new isoflavone glycoside from Dalbergia vacciniifolia (Fabaceae). Sci Pharm, 80(2), 469474.

[40] Rijhwani N and Bharty R. (2016). In Vitro Antioxidant Activity and Total Phenolic Content of Leaf Extracts of Dalbergia Sissoo (Roxb.). Int Res J Pharm, 7(8), 16-21.

[41] Swetha.U. (2017). Antioxidant Activity of Dalbergia melanoxylon Bark Extract. Int J Appl Pharm Sci Res, 2(4), 114-120.

[42] Ganga RB, Madhu KP and Vijaya RAD. (2012). Investigation of antioxidant and anti-inflammatory activity of leaves of Dalbergia paniculata (Roxb). Asian Pac J Trop Med, 5(6), 455-458.

[43] Li J and Chen D. (2013). Antioxydant activity of the extracts from Dalbergia odorifera T. Chen leaves in vitro. Med plant, 4(6), 58-61.

[44] Dalarmi L, Bezerra da Silva C, Marina Szabo E, Maria Soares de Oliveira D, de Oliveira M, Bednarczuk de Oliveira V, Zanin SMW, Dias J FG, Miguel OG and Miguel MD. (2017). Dalbergia brasiliensis Vogel Extracts in vitro Antioxidant Activity and Phytotoxic Effect in Lactuca sativa and Allium cepa. Int J Sci, 3(04), 80-87.

[45] Deng J, Wang Y and Shi L. (2018). Optimization of extraction process and antioxidant activity of polyphenols from leaves of Dalbergia sissoo (Roxb.). For Res, 31(6), 161-167.

[46] Rani R, Arora S, Kaur J and Manhas RK. (2018). Phenolic compounds as antioxidants and chemopreventive drugs from Streptomyces cellulosae strain TES17 isolated from rhizosphere of Camellia sinensis. BMC Complement Altern Med, 18(1), 1-15.

[47] Bermúdez-Oria A, Rodríguez-Gutiérrez G, Fernández-Prior A, Vioque B and Fernández-Bolaños J. (2019). Strawberry dietary fiber functionalized with phenolic antioxidants from olives. Interactions between polysaccharides and phenolic compounds. J Chem Inf Model, 53(9), 1689-1699.

[48] Nieto JA, Santoyo S, Prodanov M, Reglero G and Jaime L. (2020). Valorisation of grape stems as a source of phenolic antioxidants by using a sustainable extraction methodology. Foods,9(5), 1-17.

[49] Nardos A and Makonnen E. (2017). In vivo antiplasmodial activity and toxicological assessment of hydroethanolic crude extract of Ajuga remota. Malar J, 16(25), 1-8.

[50] Mfopa AN, Derick C, Mbouna J, Yamthe LR, Aimée M, Tchuente T, Kouipou RMT, Fokou PVT, Kemgne EAM, Kamkumo RG and Boyom FF. (2017). In vitro and in vivo antiplasmodial activity of extracts from Polyalthia suaveolens, Uvaria angolensis and Monodora tenuifolia (Annonaceae). Int J Biol Chem Sci, 11(1), 118-130.

[51] Couto J, Tonk M, Ferrolho J, Antunes S, Vilcinskas A, de la Fuente J, Kouipou RMT, Fokou PVT, Kemgne EAM, Kamkumo RG and Boyom FF. (2018). Antiplasmodial activity of tick defensins in a mouse model of malaria. Ticks Tick Borne Dis, 9(4), 844-849.

[52] Biruk H, Sentayehu B, Alebachew Y, Tamiru W, Ejigu A and Assefa S. (2020). In Vivo Antimalarial Activity of 80 \% Methanol and Aqueous Bark Extracts of Terminalia brownii Fresen . ( Combretaceae) against Plasmodium berghei in Mice. Biochem Res Int, 1-7.

[53] Songsiang U, Wanich S, Pitchuanchom S, Netsopa S, Uanporn K and Yenjai C. (2009). Bioactive constituents from the stems of Dalbergia parviflora. Fitoterapia, 80(7), 427-431.

[54] Beldjoudi N, Mambu L, Labaïed M, Grellier P, Ramanitrahasimbola D, Rasoanaivo P, Martin MT and Frappier F. (2003). Flavonoids from Dalbergia louvelii and Their Antiplasmodial Activity. J Nat Prod, 66(11), 1447-1450.

[55] Zhao X, Wang C, Meng H, Yu Z, Yang M and Wei J. (2020). Dalbergia odorifera: A review of its traditional uses, phytochemistry, pharmacology, and quality control. J Ethnopharmacol, 248, 112328.

[56] Liu R, Wen X, Shao F, Zhang P, Huang H and Zhang S.(2016). Flavonoids from Heartwood of Dalbergia cochinchinensis. Chinese Herb Med, 8(1), 89-93.

[57] Daskum AM, Godly C and Qadeer MA. (2019). Effect of Senna occidentalis ( Fabaceae ) leaves extract on the formation of $\beta$ - hematin and evaluation of in vitro antimalarial activity. Int J Herb Med, 7(3), 46-51. 
[58] Al-Snaf AE. (2017). Chemical constituents and pharmacological effects of Dalbergia sissoo - A review. IOSR J Pharm, 07(02), 59-71.

[59] Hassan FI, Abdulkadir Umar Z, Umar Habib D and Abdullahi HY. (2016). Effect of methanol leaf extract of Dalbergia saxatilis Hook.f (fabaceae) on renal function. Avicenna J phytomedicine, 6(6), 592-596.

[60] Melo E, Ramos R and Almeida S. (2016). Phytochemical Study, Chemicalphysical Analysis and Toxicological Testing of Stem Bark of Dalbergia monetaria L. f. Br J Pharm Res, 12(4), 1-7.

[61] Anisuzzman M, Hasan MM, Acharzo AK, Das AK and Rahman S. (2017). In Vivo and in Vitro Evaluation of Pharmacological Potentials of Secondary Bioactive Metabolites of Dalbergia candenatensis Leaves. Evidencebased Complement Altern Med, 1-10. 